\title{
Power and Responsibility at the Margins: The Case of India in the Global Refugee Regime
}

\author{
RANABIR SAMADDAR
}

\begin{abstract}
Based on a study of the Indian experience of refugee protection, the article poses the issue of responsibility as a critical counterpoint to the question of power. Power may produce influence and power may be an element of influence. But how do we relate power to responsibility? Given the dominant discourse of "responsibility to protect" as part of the global governance regime, the article asks if there is a different way to conceptualize responsibility in the post-colonial context. Here the article seeks to make a second intervention. Responsibility takes us to the perspective of the margins.
\end{abstract}

\section{Résumé}

À partir d'une étude de l'expérience indienne relative à la protection des réfugiés, larticle pose le problème de la responsabilité comme contrepoint crucial à la question du pouvoir. Le pouvoir peut être influent ou être un élément d'influence. Mais comment faisons-nous le lien entre pouvoir et responsabilité? Étant donné le discours dominant de «responsabilité à préserver" dans le cadre du régime de gouvernance internationale, cet article pose la question de savoir sil existe une autre manière de conceptualiser le problème de la responsabilité dans le contexte postcolonial. C'est à ce niveau qu'il cherche à faire une seconde intervention. La responsabilité nous amène à la perspective de la marge.

\section{Power, Influence, and Responsibility}

$\tau \mathrm{n}$ any discussion on power and influence in the global refugee regime, one crucial question to emerge from Indian experiences that reflects worldwide post-colonial experiences is, What is the nature of this power and influence at the margins? This question is important because, unlike the Kantian world, the world we live in is characterized by a great dissociation of power and responsibility. Wars may be launched on countries by great powers, but the burdens of refugee flows that wars create are shouldered by countries that had little to do with them. Wars in and population flows from Syria, Iraq, Yemen, Afghanistan, and Libya readily come to mind, as do the Vietnam War and disintegration of Yugoslavia twenty years later, followed by massive refugee flows. Millions of Partition refugees in South Asia had little to do with the colonial decision to divide the Indian subcontinent. Yet through all these years the global refugee regime never questioned this dissociation-primarily for two reasons. First, in the age of democracy, responsibility is understood to rest with the people, who must conduct themselves responsibly to prove that they are masters of their destiny; in other words, they self-determine, while in reality power is exercised by the corporate class. Second, international responsibility is exercised by the nation-states, while power is vested in transnational agencies and empires who exercise power without responsibility. In this situation of graded responsibility and the hierarchical history of the notion of responsibility, it is important to inquire about the nature of power and responsibility at the margins.

In discussions on power, the context of protection is of primary importance, for we are discussing how the function of protection, the ability to protect, a specific mode of

(C) Ranabir Samaddar, 2017. This open-access work is licensed under a Creative Commons Attribution-NonCommercial 4.0 International License, which permits use, reproduction and distribution in any medium for non-commercial purposes, provided the original author(s) are credited and the original publication in Refuge: Canada's Journal on Refugees is cited. 
care produces power, which is both positive and dominating. This article will unravel this dual nature of power.

Also there remains one more introductory point. The socalled regime of protection cannot address displacement due to war. The present massive refugee flows are not marked by mere discrimination or liminal violence, but brutal war The 1951 Convention barely touches the problem. It refers to war in the context of the Second World War, or to rule out protection to persons accused of war crimes. This is the background in which the question of responsibility for war and displacement assumes urgency. In war and war-like conditions the categorical distinctions between groups seeking shelter, assistance, and protection vanish. In such a time it is important to examine the effectiveness of the global protection apparatus for the refugees. ${ }^{1}$

We evaluate the responsibility of people and groups by how they exercise their power. Sometimes we do this formally, such as in a legal judgment. The question will be, How do we relate moral responsibility and legal responsibilitynot only of individuals but of empires, global powers, and other collectives? The refugee protection regime has no idea of (1) responsible agency, whereby an institution such as the state is regarded as a moral agent; (2) retrospective responsibility, by which a state is judged for its actions and is blamed or punished; or (3) responsibility as a virtue, for which a state is praised as being responsible. In the context of post-colonial experiences, we need a wider view of responsibility in order to explore connections between moral and legal responsibility, and between global and national responsibilities.

It is only from the margins that the contradictions and fault lines in the architecture of power, influence, and responsibility can be brought to light, therefore the need for a perspective "on the margins" of the protection regime is strategic. After all, there are asymmetries inherent in the fact that an overwhelming part (by some calculations, 86 per cent) of world's refugees are hosted in the Global South, ${ }^{2}$ but an equally overwhelming part (for instance, 80 per cent) of UNHCR's funding comes from states in the Global North. ${ }^{3}$ Yet we try desperately not to draw the only possible conclusion, that this asymmetry means that donors have power and host states have responsibility. As we shall show subsequently, the expanded mandate of the global protection regime to the needs of a wider set of "persons of concern" does not alter or significantly modify the wide divergence between the root causes of displacement in the Global South and the 1951 Convention, which remains finally a "persecution-centric" approach. Of course, this is not a new point. The question first appeared in the discussion in Escape from Violence almost thirty years ago. 4

This article will therefore examine the dynamics of responsibility at the margin. In this context it will discuss how the experience of refugee flows into India since independence has conditioned her engagement with the global refugee regime, including contradictions in state policies on refugees and the policy of giving asylum. The article will argue that the relation between care and power is not a simple causal one, as if simply by caring one amasses power. The relation is complex. Care does not simply flow from the sovereign legal authority at the top. The heterogeneity of power builds up and draws on the heterogeneity of the act of caring. At the same time the dispersed state of responsibility orients the power to care. This will be the basis of a post-colonial interrogation of the global protection regime of refugees and the stateless. India not only offers a story of protection and hospitality but is also an eloquent example of how post-colonial political power had a long reciprocal relation with responsibility.

\section{The Indian Story of Hospitality}

The Indian story poses the classic question of how one can study the dynamics of hospitality. ${ }^{5}$ Can it be a policy study? Can there be a policy for "hospitality," a policy to be "kind"? Or do we want to study institutions involved in practices of care and hospitality? If the state must practise care and hospitality and exercise power for the relevant practices, do these two functions (providing care and exercising power), which appear to be separate and distinct, build on each other? From this arises the broader question: from where does the capacity to care grow?

In a study of refugee protection by the state, these questions mean attending to the specific Indian arguments and experiences in (1) the definition of the term refugee and its scope; (2) the concept of non-refoulement (the principle of no forcible return) and its scope; and (3), the administrativejudicial machinery to determine the status of a shelterseeker as a refugee and, once determined, the quantum of assistance the shelter-seeker needs and gets. ${ }^{6}$ It also means trying to understand where the refugee features in such policy formulation.7 Easy physical accessibility, cultural and economic networks, and political support of host government and communities are significant elements in refugee policy-these are elements that orient care. But they also add to the power of the state to decide who will be offered hospitality and who will be denied. ${ }^{8}$ India did not sign the Refugee Convention of 1951 or the Additional Protocol of 1967. In acts of "calculated kindness,"9 some refugees were saved, cared, and rehabilitated in this country, while many were left out, refused, and neglected in the same period in and by the same country.

Refugees from Burma were welcomed as the Second World War ended, ignored in the seventies to nineties of the last century, and prevented or obstructed from entering India at yet another point as the new century began. 
Similarly, while some groups of refugees such as the Tibetans were almost allowed to be "Indianized," other groups such as Sri Lankan refugees still spend long years in India in strictly watched camps. The logical structure of these contradictions and ambivalence in India's asylum policy has been termed "strategic ambiguity." 10 In some cases, as after the birth of Bangladesh in 1971-2, refugees returned quickly by the thousands, while after 1959 the Tibetan refugees stayed and the Indian state did not even attempt to persuade them to go back. In contrast, the state according to some wanted to forcibly repatriate the Chittagong Hill Tracts refugees in Tripura in the 1980s-1990s, and the Sri Lankan refugees in Tamil Nadu from the mid-198os.

However, such differential treatment of refugees and asylum seekers is not the full history of the hospitality of the Indian state. Many writers have chronicled how refugee care in post-Partition Punjab and Bengal became part of building the new India. One chronicler commented, "The history of relief and rehabilitation in the east is one of gradual emplacement within a national body of those who were the victims of one of the world's worst population displacements. The travails and trauma that accompanied their emplace ment are only reflective of our fledgling nationhood." 11 The chronicler of relief and rehabilitation in the West wrote in similar vein, "It was the characterisation of the refugee as a critical component of nation-building that marked a significant shift in conceptualisation and, consequently, in policy formulation. Linking resettlement with development, and rehabilitation with reconstruction, was a uniquely progressive and far-sighted response to a problem of crushing proportions; in this scheme of things refugees became a valuable human resource rather than, only, an onerous liability." ${ }^{12}$ In contrast Joya Chatterjee shows that it was a time marked by the two contending notions of right and charity, ${ }^{13}$ but there is a fundamental agreement among all actors in that contentious scenario that we/they are part of the nation, the nation must accept us/them. In this dual context of nationalism and democracy there is not only a re-emphasis on "Partition refugees" as elements of nation-building, but also a reinforcement of the state's duty to care and its imperative to mobilize all its powers to that end-indeed, to justify its status as the repository of power, the state had to rearticulate its obligation to care. The birth of social security was made possible by detailed governmental policies and techniques for sheltering the refugee population, the expanding universe of nation, and the daily contest between the state and the refugee population that became another segment of the population being governed. ${ }^{14}$

Thus not the security explanation, or the kindness explanation, or even the international law and international regime explanation will be enough to make us understand the mysteries behind one of the most observed and least comprehended political phenomena of our time, namely the asylum and refugee care policy of a post-colonial state. One may argue that a rights-based explanation may appear as the best route, because the refugees of Partition viewed their own arrival in India as a matter of right-returning home, returning to the "natural nation." Yet the situation was ambiguous (the nation was not so "natural," and the departure too was from a "home"), and refugee protection did not evolve purely as a matter of right of the refugees, because it also evolved as an ethical, humanitarian task involving the principle of responsibility towards the subjects of the nation.

Several accounts of the Tibetan refugees in India have shown that refugees are not always a burden; they can be creative and productive, and they can add to the wealth and colours of life. ${ }^{15}$ In other instances, refugees became murderers, as the history of the Taliban growth in Pakistan suggests. Therefore ethics exists beyond law or refugee rights, though one can reasonably inquire as Derrida did, Can one "cultivate an ethic of hospitality? Hospitality is culture itself and not simply one ethic among others." 16

There are ten main features of major forced population movements into India in the last sixty-nine years and the responses of the Indian state towards them:

1. The first refugees to arrive in independent India were not aliens who needed shelter; they were part of the nation.

2. The first practices of refugee care and administration built up not so much through law as through rehabilitation and social security.

3. Institutions are the concrete results of these practices, and laws that result in a tradition of hospitality, which the state can neither fully endorse nor reject.

4. "Partition refugees" have left a mark on the subsequent pattern in which the state has combined care with power; this is the mark of ambiguity.

5. The contest between the notions of charity and rights that began when refugees started pouring in has influenced the discourse of "hospitality," a term that is supposed to overcome the contradiction. The current discourse on refugee protection in India arises from this contest between the two notions.

6. The foundations of the legal-administrative discourse on refugees and foreigners were in that strategic ambiguity. Who became alien, when, and declared by whom became a deeply circumstantial matter, never to be defined by law.

7. Alien-hood thereby became a second part of a democratic state, which required and created the citizens as its political foundation.

8. Because offering shelter and protection became deeply circumstantial, including near-permanent residence, 
local communities responded with charity and fatigue, benign care and ill feeling and animosity-a response that also characterized the conduct of the state. Local response and responsibility influenced state policy on refugees.

9. Keeping shelter-seekers in ghettos, proscribing their movement, creating penal colonies, thus underwriting the nature of charity that the state had been providing, become a feature of the asylum and care practices of the state, though with some exceptions. What began in the Andaman Islands and Dandakaranya continuesprotecting and penalizing have become interlinked responsibilities.

10. Finally, the Convention of 1951 was powerless to change the state's decision between visitation and residence. Thus, refugees who thought when they arrived in India in 1947 that they would go back, did not, and the state never told them to go back; similarly, the Tibetan refugees have not been told to go back, nor have they been repatriated. On the other hand, thousands of refugees from East Pakistan went back as soon as the war of 1971 was over. Some Chakma refugees flowing into India stayed, some went back, and some had to be induced to go back. In some cases, the state allowed the refugees to come in, then inexplicably shut the door on them. The enigma is therefore not so much in India's non-accession to the Convention, but in the way the state defines and configures its responsibility.

Refugee flows to India in time became massive and mixed. Possibly it had always been so. The foundational history of care in independent India involves countless shelter-seekers. Now, the two discourses have become linked-the issue of illegal immigrants and that of refugees. Both influence, predicate, and prejudice the other. ${ }^{17}$

\section{Judicial Reasoning}

How has the justice system in India responded to this deeply equivocal relation? How has juridical reasoning been shaped in this context? Drawing from a larger study on this theme, ${ }^{18}$ I shall restrict this account to the main features of judicial reasoning in India and a few examples.

In a Court decision in India, five Burmese nationals detained for entering India without valid documents and charged under the Foreigners' Act of 1946 (hereafter the FA) were granted bail by the Guwahati High Court so that they could apply for refugee status from the UNHCR in New Delhi. Their application was subsequently granted and the case was withdrawn by the prosecution (unreported, State v KhyHtoonand 4 others, FIR No 18 (3) 89, CJM, Manipur, 1994). In another case, an Iraqi national detained for using a forged passport was authorized to stay in India and the Court ruled that since he had valid certification from the UNHCR with him, he could not be convicted for the offence. Considering that he was a refugee the Court took a lenient view and sentenced him to pay just a fine (unreported, State v Muhammad Riza Ali, FIR No 414/93, Cмm New Delhi, 1995). Similarly a Sudanese woman who had come to India to escape further torture in Sudan, where she had been gang-raped for converting from Islam to Christianity, had been granted refugee status by the UNHCR. In this case too, though she had been charged under the FA, the Court levied only a small fine and imprisonment of ten days already served (unreported, State v Eva Massur Ahmed, FIR No 278/95, MM-New Delhi 1995).

In another case concerning a Burmese national who had fled to India, had been detained under the FA, and had not been able to approach the UNHCR, the Court ordered conviction and rigorous imprisonment for six months and deportation back to Burma. The Court also ruled that on completion of the sentence and in response to appeal, it was not within its jurisdiction to hand over the convicted to the UNHCR (unreported, State v Benjamin Zang Nang, GR case no 1253 (1994), ACJM, Sealdah, West Bengal, 1996).

Did refugees have freedom of movement? A Sri Lankan who had been granted refugee status and was staying in Chennai was arrested in Delhi for being unable to produce a valid travel document, and detained under the FA. The Court observed that refugee status did not entitle a person to move about freely, found him guilty, and sentenced him to six months of rigorous imprisonment (Unreported, State v Hudson Vilvaraj, FIR No 583/97, MM, Delhi, 1998). And what about refugees who forged passports or travel documents to take shelter in the country? Almost uniformly, the Courts held that such acts constituted offence under the FA, sentenced somewhat lightly, and wherever the government had pleaded a foreigner's stay a threat to security, had ordered expulsion/deportation, or had said that further stay depended on government permission (for example, unreported, State v Muhammad Yashin, FIR No 289/97, SMM, Delhi, 1997).

And then there was a strange case of perfect ambiguity. A woman, arrested on the grounds that she was a Burmese national and had violated the FA, produced her birth certificate, residence certificate, employment certificate, and a copy of the electoral roll that listed her as a voter. The Court ordered her free on the grounds of evidence, but it wondered why, though she claimed to be a permanent resident of Mizoram, she could not speak the Mizo language, and found it strange that she had an original birth certificate, and had been allotted permanent residence in Mizoram, particularly when the issue of foreigners was a burning issue in the state (unreported, State v Sungenel, GR No 979/96, ADC/Judicial Officer, Aizwal, Mizoram, 1996). 
Thus, the juridical reasoning has assumed that the burden of protecting an asylum seeker lies with the UNHCR. This includes the burden of resettlement, and the conditionality that the detained foreigner would not be able to move out to another place of choice without certification and assumption of responsibility by the UNHCR. In such reasoning the Court has held that, as much as possible under the circumstances, the state should show leniency to offenders who had violated the Foreigners Act. It has been recognized that not only persecution of a particular person, but a general atmosphere of violence and insecurity can also be grounds for asking for shelter; and if the state claims that state security is in jeopardy, then expulsion or deportation must be the norm. The state may not be obliged to grant asylum, and the duty of hospitality may not be legally enforceable, yet the Court expects that the state will practise hospitality as much as possible, based on its own power to determine the period of visitation according to particular circumstances.

Indeed, the Gujarat High Court summarized the position (unreported, Kfaer Abbas Habib Al Qutaifi and Taer Ali Mansoon, Civil Rule No. 3433 of 1998) in the context of India being a non-signatory to the 1951 Convention:

1. The relevant international treaties and convention are not binding, but the government is obliged to respect them.

2. Article 21 of the Constitution is enjoyed by a non-citizen on Indian soil, implying the principle of non-refoulement, but this does not confer on the non-citizen a right to reside and resettle, nor does it mean that if the stay of a non-national is contrary to national security, she or he can stay.

3. Where the international covenants and treaties reinforce the fundamental rights in India, as facets of those rights they can be enforced.

4. The power of the government to expel a foreigner is absolute.

5. The work of the UNHCR in certifying refugees is humanitarian, so the government has an obligation to ensure that refugees receive international protection until their problems are solved.

6. Finally, in view of Article 51 that directs the state to respect international legal principles, the Courts will apply those principles in domestic law in a harmonious manner, provided such obligations are not inconsistent with domestic law.

The Supreme Court has also concurred with the judicial practice of assigning the burden of protection on the UNHCR, and has ruled that the issue of "reasonable procedure" in asking a non-national to leave the country arises only when there is UNHCR certification of the non-national as refugee, and not otherwise. The Court has not laid down any standard norm in sheltering or certifying a refugee. Thus there is an unwritten division of labour: the UNHCR has exercised its mandate mainly with regard to 12,00o Afghan refugees and 1,00o refugees of other nationalities; in some other cases, it has been allowed to carry out relief and settlement work; in other cases, the government has decided the fate of the shelter seeker. Thus in case of some 100,000 Tibetan refugees, and some 65,000 Sri Lankan refugees, the UNHCR does not have a direct role. The mandate refugees assisted by the UNHCR are Afghans, Burmese, and small number of Iranians, Sudanese, Iraqis, and others. Through the Foreigners Regional Registration Office the government issues renewable residential permits to mandate refugees on the basis of certificates issued by the UNHCR. Yet cases before the courts continue involving refugees undergoing legal process for illegal entry. Visible and invisible frontiers have been created. The feature of these nouvelles frontieres is that they are being produced internally also; they are not merely vertical lines separating two spaces, but concentric circles continuously dividing and then locating these lines to rejoin them in the universe of the nation. Law, citizenship, rights, obligation, and morality-all are caught in this universe of concentric circles, where difference and identity both jostled for space in the scheme of things. ${ }^{19}$

Between 1950 and 1975, the Indian government signed treaties of peace and friendship with Bhutan, Sikkim, Nepal, Burma, Sri Lanka, and Bangladesh, and an odd pact with Pakistan on minorities. These treaties bore assurances of friendship on behalf of an independent and anti-colonial state. These agreements were based on and reproduced the geopolitical imaginary of an imperial nation engaged with territory and population (as in the agreement between India and Sri Lanka on the Indian Tamil plantation labour in Sri Lanka). Territory was fixed; so also was the attempt to fix the population. Like combating famine, combating population instability has been a task of great magnitude. People of Indian origin who had settled overseas were to give up what we might now call a "right of return," just as partition refugees once nationalized by being allowed to acquire citizenship were to give up the "right to return." Population flow in the understanding of the modern state has queered the pitch in the state's effort to establish a singular and unitary relation between place and identity-the hallmark of the modern state's existence. But as accounts of transborder migration in South Asia demonstrate, the effort to discount the existence of people whose identities bear only faint resemblance to the professed national identity of the state has proved impossible. $^{20}$

In sum, this discussion shows that judicial reasoning (which includes legal reasoning) is the instrument to balance power and responsibility, and as the reason it has guided the 
Indian state to frame its policy of hospitality in a combination of power and responsibility. Judicial reasoning is the congealed expression of the tensions central to the argument of this article.

\section{Stateless Population Groups}

We now come to the issue of statelessness. Research in refugee studies tells us that protracted displacement and refugeehood leads to potential loss of citizenship in the home country and, as a consequence, de facto statelessness. ${ }^{21} \mathrm{~A}$ serious investigation into the conditions of statelessness in India will reveal once more the disjunction between the formal protection regime led by the UNHCR and the evolving norms, conditions, and protection practices. ${ }^{22}$ The framework of protection for the stateless in India is distinctly post-colonial It is derived from the partitions and the decolonization in South Asia, where nowhere people abound in the borderlands, ${ }^{23}$ and it is at odds with the paradigm of protection of the stateless, which emphasizes the requirement that the state from where the stateless have come and the state they look to for protection must recognize that the groups/ individuals/communities are not their citizens. International legal wisdom is therefore inattentive to the ways in which de facto statelessness has been produced in the region. Unlike the legalistic interpretation of statelessness, statelessness in the post-colonial context is seen less as a positive definitionone that sets out complete conditions for statelessness-and more as refraction of citizenship. Citizenship is seen as an institution that always "incompletes" itself. Actual experiences of statelessness therefore offer a definition that bases itself on displacement of reality-the reality of state, nationality, and citizenship. Not surprisingly then, post-colonial research on statelessness is in effect a study of permanent incompleteness-a reality that always seems to fall short of a hyperreality, and therefore the ideal reality, of citizenship, entitlements, legal protection, fully proven identity, recognitions by courts of law, and the avowals by the state.

In some sense this tension was anticipated by the United Nations in its early years when it first broached the idea of de facto statelessness, ${ }^{24}$ which is different from refugee law. While refugee law is de jure (even when we speak of a "refugee-like" situation, because law can be only de jure), in the Convention on Statelessness, the law tries to define de facto, which is supposedly not de jure. But if the de facto is defined or annotated legally, it almost becomes de jure. As we shall see, the entire South Asian situation symbolizes this tension and thus constrains UNHCR's activities on statelessness in South Asia. ${ }^{25}$

Article 1 of the 1954 International Convention relating to the Status of Stateless Persons defines a "stateless person" as someone who is not recognized as a national by any state under its law. According to the International Law Commission, the definition of stateless persons contained in Article 1 (1) of the Convention now forms part of customary international law. The Article defines "stateless persons" as those who therefore have no nationality or citizenship and are unprotected by national legislation and left in the arc of vulnerability. The stateless therefore have no nationality or citizenship and are unprotected by national legislation and left in the arc of vulnerability. Whether or not a person is stateless can be determined on the basis of an assessment of nationality laws and how these laws are implemented by the state. Since nationality is generally acquired on the basis of a link between the individual and the state-some kind of connection either with the territory (place of birth or residence) or with a national (descent, adoption, or marriage) - it is therefore held important to look at the nationality legislation and practice of states with which an individual enjoys a link in order to see if nationality is attributed to the individual under any state's law. If not, then he or she is stateless. Yet we must understand that the law on statelessness is heavily influenced by the European experiences of succession of states and does not take into account the post-colonial experiences of partitions and decolonization. Thus the UNHCR finds it difficult to understand the de facto stateless nature of several population groups in India, such as the Chakmas in Arunachal Pradesh, who were encouraged by the Government of India to take shelter in the desolate North East Frontier Agency (now Arunachal Pradesh), India, when they were uprooted from Chittagong Hill Tracts, Bangladesh (erstwhile East Pakistan) after the building of Kaptai Dam in 1964.

Let us go back once more to the 1954 International Convention relating to the Status of Stateless Persons. It refers to the category of de facto stateless persons-who remain outside the country of their nationality and hence are unable unwilling to avail themselves of the protection of that country. "Protection" in this context refers to the right to diplomatic protection exercisable by a state of nationality in order to remedy an internationally wrongful act against one of its nationals, as well as diplomatic and consular protection and assistance, generally including her return to the state of nationality. Again, Article 15 of the Universal Declaration of Human Rights says, "Everyone has a nationality. No one shall be arbitrarily deprived of his nationality, nor the right to change his nationality." It implies, first, that one cannot have the option of remaining stateless, and second, deprivation of nationality or denial of the right to nationality is possible, provided it is not "arbitrary." International law empowers the state to determine who are its citizens. The operation of law must be in accordance with the principles established by international law. 
On the basis of South Asian experiences, one can argue that while statelessness may emerge from succession of states or territorial reorganizations, it can also emerge from persecution of minorities due to a state's majoritarian bias and consequent disenfranchisement, which may lead to expulsion of groups of inhabitants. This condition, reinforced by the protracted refusal of the involved states to take them back, may lead to loss of their nationality and citizenship. A classic emergence of a stateless population is that of the Rohingyas in Bangladesh and India. While residents of border enclaves did not strictly fall into the category of the stateless, they were subject to harsh border control practices and regulations, that negated their formal citizenship. On the other hand, Hindu refugees from Pakistan and Tamils of Indian origin continue to live in the camps of Tamil Nadu and are yet to be granted citizenship. Together they illustrate the prevalence of de facto statelessness in the post-colonial world. But statelessness is not simply a legal problem or a humanitarian problem; it is a political problem as well. Can pure legal mechanisms work in such a complex situation? Is it adequate to look upon statelessness simply as an interstate problem? Suffice it to say that dialogue with the UNHCR has proven ineffective in the face of UNHCR's absolute disregard for the de facto stateless situation in South Asia, its complexity, and the politicaladministrative-juridical practices of the state with regard to these groups. ${ }^{26}$ There is a need to study the judicial, administrative, and political decisions of the Indian state to host these groups within the confines set by the Citizenship Act (1955), Foreigners Act (1946), and measures regarding the aliens in the British statutes applicable to India (the British Nationality and Status of Aliens Act, 1914). ${ }^{27}$

Statelessness seen in this light is more a set of conditions that limit experience. Such an understanding must at one point brush against the law. The function of international law is to tell society the limits of institutions such as border, state, citizenship, rights, humanitarianism, and constitution. If the subject of the state is the citizen, the stateless is the alien.

The study of stateless populations will become increasingly significant in forced migration studies. As states go to war, rise, and fall, countries fight new forms of colonialism and new forms of decolonization occur, borders and boundaries play havoc with settled configurations, the number of stateless population groups will increase. We may see a reduction of de jure statelessness, but a rise in de facto stateless populations around the world. It may also become increasingly difficult to distinguish between a refugee group and a stateless group. Newer identity practices imposed by states may produce stateless condition. If the preceding century was one of partitions, this century may become known as the century of stateless people marked by diverse state practices.

\section{Concluding Observations}

Let us now connect the threads in this article by revisiting the main argument, that the other scene of power and influence in the global refugee regime is that of power and responsibility at the margins. Too often we focus on the global regime of power and influence that mark the protection regime, while ignoring the dynamics of responsibility that mark the protection scenario at the margins. As a result our critique too has suffered from a top-down approach. Posing from the margins the question of responsibility is a post-colonial reflection of the way power is organized. In that sense the question posed in the article has a broader significance, for the implication is that we must examine the dynamics of responsibility whenever we study power.

The post-colonial framing of responsibility will mean taking into account the background of decolonization, partitions, structural reforms, environmental disasters, and neoliberal development against which population flows continue. The article has argued that against this background of continuing population movements, the legal definitions of the victims of forced migration and their protection norms are starkly inadequate. Because this is the postcolonial reality, it is important to study the local dynamics of power and responsibility in protection of the victims of forced migration. This article argues that we need to study local and variegated experiences of refugee protection, because there is a greater burden of protection at the micro level-at the margin.

One may argue that the power and influence of the global refugee regime is largely ineffective against the realities of the post-colonial world. The migrant has emerged as a significant subject ${ }^{28}$ under conditions of globalization, aggressive wars, transgression of borders, and a political economy that allows differential inclusion of migrant labour. But if the post-colonial experiences suggest plural responsibilities for protection and hospitality, it means that we must accept legal pluralism as the foundational principle for rebuilding the architecture of protection. ${ }^{29}$

While not all post-colonial experiences are the same, the article suggests that the Indian experience is indicative of a general experience and problematizes assumptions about the experience of states on the margins of the international system.

\section{Notes}

1 Margaret E. McGuiness discusses the 1951 convention's "limited nature of the definition of a refugee" in "Legal and Normative Dimensions of the Manipulation of Refugees," Refugee Manipulation: War, Politics, and the Abuse 
of Human Suffering, ed. Stephen John Stedman and Fred Tanner (Washington, DC: Brookings Institution Press, 2003), 135-66; on the politics of encouraging secessions in former Yugoslavia, the resultant Balkan war in the 1990s, and the refugee flow, see Joseph Rudolph Jr., "The Doubtful Effects of Military Intervention on Forced Migration in Yugoslavia," in The Politics of Forced Migration: A Conceptual, Operational, and Legal Analysis, ed. Nina Nachmias and Rami Goldstein, 191-224 (Baltimore: Publish America, 2004).

2 UNHCR, Global Trends: Forced Displacement in 2015, www .unhcr.org/576408cd7.pdf.

3 UNHCR, "Contributions to UNHCR for Budget Year 2015 (as at 31 December 2015)," http://www.unhcr.org/partners/donors/558a639f9/contributions-unhcr-budget-year2015-31-december-2015.html.

4 Aristide R. Zolberg, Astri Suhrke, and Sergio Aguayo, Escape from Violence: Conflict and the Refugee Crisis in the Developing World (1989; Oxford: Oxford University Press, 1992).

5 In ancient philosophies the question of hospitality was significant in determining personhood. For example, Pericles said in the funeral oration speech, "Our city is thrown open to the world, and we never expel a foreigner or prevent him from seeing or learning anything of which the secret if revealed to an enemy might profit him." The History of the Peloponnesian War in Complete Works of Thucydides, trans. Benjamin Jowett, 2nd. ed. (Oxford: Clarendon, 190o), bk. 2, para. 39; see also on hospitality, Cicero, On Duties, ed. M.T. Griffin and E.M. Atkin (Cambridge: Cambridge University Press, 1991), bk. 2, 86-89; of the Indian classical texts the Mahabharata deals at length with hospitality. In this connection see the discussion by J. Derrida, On Cosmopolitanism and Forgiveness (London: Routledge, 2001).

6 In his address to the Roundtable Workshop on Refugees in the South Asican Association for Regional Cooperation (SAARC) Region, the president of SAARCLAW (India Chapter), A.M. Singhvi admitted that these questions of state obligations needed to be viewed in the context of human rights. The debate on the need for a national refugee law in India and the work on a model law has been conducted, however, often from a courtroom angle, and not from the perspective of massive and mixed flows-though it must be admitted that such debate represents a clear advance from the earlier state of affairs in policy matters. On the address, see Report on Roundtable Workshop on Refugees in the SAARC Region: National Legislation on Refugees, SAARCLAW and UNHCR, New Delhi, 30 April 1999, 13-18.

7 Clearly in the present European migration crisis, refugees have become forced themselves as active subjects in policy formulation.

8 Report on Roundtable Workshop on Refugees, 21.

9 G. Loescher and J. Scanlan, Calculated Kindness: Refugees and America's Half-Open Door, 1945-Present (New York: Free, 1986).
10 B.S. Chimni, "Status of Refugees in India: Strategic Ambiguity," in Samaddar, Refugees and the State, 443-71.

11 S.K. Das, "State Response to the Refugee Crisis: Relief and Rehabilitation in the East," in Samaddar, Refugees and the State, 147.

12 R. Menon, "Birth of Social Security Commitments: What Happened in the West," in Samaddar, Refugees and the State, 186 (emphasis added); on the complex process of forging a new identity among refugees in the western part of India, Ravinder Kaur, Since 1947: Partition Narratives among Punjabi Migrants of Delhi (New Delhi: Oxford University Press, 2007).

13 J. Chatterjee, "Rights or Charity? Government and Refugees: The Debate over Relief and Rehabilitation in West Bengal, 1947-1950," in Partitions of Memory, ed. S. Kaul, 74-110 (Delhi: Permanent Black, 2001).

14 The lasting significance of the Indian experiences of hosting and finally accommodating the Partition refugees is embedded in the critical question of legitimacy: thus, why is the Indian state legitimate? Because it accommodates the shelter-seekers, or, how long can India accommodate them? Again, India has a duty to the kin states and the other poor states. But this does not mean that that the protection policy has not changed over the years. But the strategic ambiguity this article refers to evolved from the times of Partition in 1947 and the following decade, and remains, notwithstanding the particular differences.

15 See, for instance, D. Norbu, "Refugees from Tibet: Structural Causes of Successful Settlements," Tibet 26, no. 2 (2001): 3-25.

16 J. Derrida, On Cosmopolitanism and Forgiveness (London: Routledge, 2001), 16.

17 For a good summary of the refugee flows in South Asia and the state response, see Pia Oberoi, Exile and Belonging: Refugees and State Policy in South Asia (New Delhi: Oxford University Press, 2006). We also note that the Indian story greatly resembles the refugee hosting experiences and practices of other South Asian countries, such as Bangladesh hosting the Rohingyas, Nepal hosting the Tibetan refugees, and Pakistan hosting the Afghan refugees and earlier the Mohajirs. Like in the Indian case, in these three cases also the care and protection was overwhelming informal, the dynamics of kin states operated, the states were signatories to the Refugee Convention, and by and large refugees were not forcibly repatriated. On a broad and comparative study of South Asian experiences of care and protection, see Omprakash Mishra, ed., Forced Migration in the South Asian Region: Displacement, Human Rights, and Conflict Resolution (New Delhi: Centre for Refugee Studies, Jadavpur University, Brookings Institution, and Manak Publications, 2004).

18 R. Samaddar, "Refugees and the Dynamics of Hospitality: The Indian Story," in Immigration Worldwide: Policies, Practices, and Trends, ed. Uma A. Segal, Doreen Elliott, and Nazneen S. Mayadas, 112-23 (New York: Oxford University Press, 2010).

(C) Ranabir Samaddar, 2017. This open-access work is licensed under a Creative Commons Attribution-NonCommercial 4.0 International License, which permits use, reproduction and distribution in any medium for non-commercial purposes, provided the original author(s) are credited and the original publication in Refuge: Canada's Journal on Refugees is cited. 
19 I have here summarized the conclusions of the reported and unreported cases, discussed in ibid., 117-21.

20 For instance, the study by R. Samaddar, The Marginal Nation (New Delhi: Sage, 1999).

21 The Un secretary general conceded the significance of protracted displacement in creating statelessness, when he defined "stateless persons as persons who are not nationals of any State, either because at birth or subsequently they were not given any nationality, or because during their lifetime they lost their own nationality and did not acquire a new one." "A Study of Statelessness," United Nations Department of Social Affairs, August 1949 (re-edited by UNHCR, Geneva, 1995), 8; this because "the right to nationality" is seriously impaired by protracted refugee-hood. See also the discussion on the implications of de facto statelessness in constituting de facto stateless people in Hugh Massey, UNHCR and De Facto Statelessness (UNHCR, April 2010), http://www.unhcr.org/4bc2ddeb9.pdf, 13; see also for detailed case studies (stateless groups such as Chakmas in Arunachal Pradesh in India, or the Tamil plantation labour from Sri Lanka in India) on this point, Paula Banerjee, Anasua Basu, Ray Chaudhury, and Atig Ghosh, eds., The State of Statelessness in South Asia (Hyderabad: Orient Blackswan, 2015).

22 On the up-and-down history of the UNHCR in India, see Sarbani Sen, "Paradoxes of the International Regime of Care: The Role of the UNHCR in India," in Samaddar, Refugees and the State, 396-442.

23 On this, see Willem Van Schendel, The Bengal Borderland: Beyond State and Nation in South Asia (London: Anthem, 2005).

24 "Study of Statelessness."

25 The Bangladeshi expert Chowdhury Abrar has used the term virtual statelessness in the context of the Rohingyas and Biharis. See C. Abrar, "Human Rights and Human Security Issues of Virtual Stateless People in Bangladesh: The Rohingyas and the Biharis," preliminary draft, https://www .scribd.com/document/254096219/Chowdhury-Abrar-pdf. The experiential argument in discussions on statelessness has been made by others also; for instance, Victoria Redclift, Statelessness and Citizenship: Camps and the Creation of Political Space (London: Routledge, 2013), 1-31; P.R. Chari, Mallika Joseph, and Suba Chandran, Missing Boundaries: Refugees, Migrants, Stateless, and Internally Displaced Persons in South Asia (New Delhi: Manohar, 2003). Significantly Hannah Arendt also saw the tension as she remarked, "Hence our position of human rights reversed: Every man born with inalienable rights. Theirs: All men born without any rights. And the right is the right to have rights; this right is guaranteed by citizenship. If we do not stop this by having - not a bill with innumerable human rights which only highest civilizations enjoy-but one internationally guaranteed right to Citizenship-whatever this Citizenship happens to be-, we shall have more and more people who with respect to their legal status no longer are human, who have longer a place within humanity." Arendt, "Note on Stateless," unpublished, 22 April 1955, https://www.scribd .com/document/295480219/ArendtStatelesness-pdf.

26 This section is based on the findings of the Calcutta Research Group's work on statelessness in India, Statelessness, 2010-12, http://mcrg.ac.in/Statelessness/Statelessness_ Report.asp; for the full book-length study based on seven population groups, see Paula Banerjee et al., State of Statelessness in South Asia; see also two legal studies on statelessness in India and the need for new legal norms: Shuvro Prosun Sarkar, "Reducing Statelessness: A New Call for India," Refugee Watch 43-4 (2014): 76-89; and CharlotteAnne Malischewski and Shuvro Prosun Sarkar, "Stateless in Law: Two Assessments," CRG Research Article series, Policies and Practices 6o (2013).

27 Law Commission of India, Fifth Report on British Statutes Applicable to India, 1957, http://lawcommissionofindia.nic .in/1-50/report5.pdf.

28 On studying the migrant as a central factor in fracturing the protection process, Samaddar, Marginal Nation. While Marginal Nation was a more historical study and an ethnographic account, for a more detailed, global, and structural analysis, see Thomas Nail, The Figure of the Migrant (Stanford, CA: Stanford University Press, 2015); studying the post-colonial forced-migration scenario is crucial in order to understand the refugee subjectivity precisely because in the post-colonial world the refugee occupies the in-between space of abnormality and normality. See, in this connection, the study by Paolo Novak on Afghan refugees in Pakistan, "Refugee Status as a Productive Tension," Transnational Legal Theory 6, no. 2 (2015): 1-25.

29 Very briefly, my argument is that the lens of legal pluralism helps the study of the international regime of refugee protection, both in broadening our understanding of the way in which it can operate domestically, and in discovering avenues for reform. India, as a host state for refugees, has not joined and shows no intention of acceding to the major international refugee protection treaties. Nor does the possibility of a national law on refugees seem likely. Nevertheless, in practice India's government and judiciary have responded to multiple refugee situations, and in most cases the basic needs are being met and basic rights are being protected. Although India tends to be isolationist with respect to international law, the judiciary has been incorporating the aspirations of international human rights law into the domestic constitutional framework, particularly in the context of refugees and foreigners rights. These actions demonstrate limited constitutional pluralism, with the Universal Declaration of Human Rights functioning as the supra-national constitution. While constitutional pluralism validates the possibility of rights protection occurring through these avenues, it also suggests, at least in the context of refugee protection, the possibility of working

(C) Ranabir Samaddar, 2017. This open-access work is licensed under a Creative Commons Attribution-NonCommercial 4.0 International License, which permits use, reproduction and distribution in any medium for non-commercial purposes, provided the original author(s) are credited and the original publication in Refuge: Canada's Journal on Refugees is cited. 
towards regional refugee regimes that will more accurately respond to refugee population movements. The advantage of this condition is its ability to recognize a plurality of interpretations and applications of law, while still recognizing that the ethics of responsibility remains the guid ing principle. On this, see Jessica de Shanti, "Pluralisms of
Law: India's Place in the International Refugee Protection Regime," Refugee Watch 46 (2015): 73-93.

Ranabir Samaddar is director of the Calcutta Research Group in Kolkata, India. The author may be contacted at ranabir@mcrg.ac.in.

(C) Ranabir Samaddar, 2017. This open-access work is licensed under a Creative Commons Attribution-NonCommercial 4.0 International License, which permits use, reproduction and distribution in any medium for non-commercial purposes, provided the original author(s) are credited and the original publication in Refuge: Canada's Journal on Refugees is cited. 